\title{
Implementing Blended Learning to Promote Sustainable Teaching and Learning Process in Writing Class
}

\author{
Nurul Puspita ${ }^{1}$, Umar Alfaruq A. Hasyim² \\ IAIMNU Metro Lampung ${ }^{2}$ \\ Email: alfaruqedu@gmail.com ${ }^{2}$
}

\begin{abstract}
Teaching writing in the era of industrial revolution 4.0 is very challenging and interesting. This era encourages both lecturer and the student utilizing informatics technology in teaching and learning process. Since, the process of teaching writing needs more time, the classroom activities do not accomodate the whole processes such as, planning, drafting and revising. Therefore, it needs solution to sustain the teaching and learning process not only in the classroom but also outside the classroom. Blending Google Classroom and classroom activities is one of solutions to lead sustainable teaching and learning process, especially in writing class. Thus, this research aims at describing the implementation of that blended learning in teaching and learning writing. It is descriptive qualitative research that capturing the lecturer and students of English department UIN RIL Lampung in implementing blended learning. Finally, this research found that blending Google Classroom and classroom activities could make the process of teaching writing carried out completely, continuously and well-controlled.
\end{abstract}

Key words: blended learning, sustainable teaching and learning process, writing class

\section{A. INTRODUCTION}

Industrial revolution 4.0 influences all aspects of human life. In education aspects, this disruptive era gives the benefits to the process of teaching and learning. However, in English language teaching, this era provides with the ideas and devices that ease the teachers and the students in doing the teaching and learning process.

However, there is still a problem in teaching and learning English. It is stated by Gomaa in Adas and Bakir (2013:255), he argues that mother tongue influences target language being learned. In EFL context, esspecially writing skill, mostly writing product of EFL learners are influenced by their mother tongue. these encompass accuracy and composition. It is stated by Ceylan (2019: 155) that students meets the difficulties in writing mostly in the case of common expression, vocabulary, cohesion and etc. Therefore, the learners need to accustume with the vocabulary, mechanics, grammar, structure and composition that are different from their mother tongue.

Those difficulties stated above shows that mother tongue can be an obstacle for the learners to learn target language. It is happened due to the differences between mother tongue 
and the target language being lerned. However, it does not mean that target language cannot be learned or acquired. One of ways to gain success in learning English as target language is using English as habit. It means that the teachers accustume the learners with the target language.

There are four skills of English - speaking, reading, listening, and writing - that are commonly thaught in Indonesia. Those four skills have different level of dificulties. It depends on the learners cognitive level of understanding as well as the way they learn. However, writing is the most difficult skill to be mastered by the students. it is because English writing is not common in Indonesia. English writing is used in certain occasion and place. In other word, English writing is rare to be applied in the public.

Besides, writing is a process, it is a process of discovering, exploring idea and undesrtanding. Technically, there are three sreps of writing such as prewriting, writing and rewriting (Murray, 1972:4). Those proceses need time, some times the time allocation cannot accomodate them. It needs sustainable, continuous and complate control of the teacher or leacturers to the students.

Therefore, utilizing technologies is one of solution to make writing process run well. Blending classroom activities and Google classroom will promote sustainable teaching and learning process.

\section{Writing}

In learning foreign language, langauge learners begin learning a language from their mother tongue, sometimes encounter mistake (suhono, 2017:72). Moreover, language is a media for communication among individuals or people. It is a signaling system which is operated with symbolic vocal sound to get the purpose of communication. Learning English language is one of science that should be learnt to all the people. English becomes very important and useful for us (Suhono 2017:1) One of aspect of learning english is writing.

According to Richard kern, writing is functional communication,making students possible to create imagined worlds of their own design. In the other sentence, Writing is a process that occurs over a period of time, particularly if we take into account the sometimes extended periods of thinking that precede creating an initial draft. Furthermore, writing also defines as a mental activity of skilful decision-making, appropriate for the situation. It means that the writer is able to make decision as consideration to the purpose of writing, the objective of the readers in reading text, situation and condition during the process of writing done. 
Moreover, Grundy assumes that writing is like as playing tennis, it is an activity made up of several processes, such as thinking what to write and the order to put it in (1991:7). In the process, writing and thinking are so inseparable, if the researcher cannot think clearly about an idea, he cannot write well. On the contrary, if he has creative thinking in the writing process, the actual writing process will be easier. Meanwhile, Hyland states that writing is seen as a process through which writers discover and reformulates their ideas as they attempt to create meaning (2002). It is more of a problem solving activity that an act of communication. How people approach a writing task as the solution to a series of problems.

In addition, Writing consist of words and these words are put together into paragraphs. Moreover, Sari and Suhono said that - Writing involves transferring a message from our thoughts using language in the written from. By writing, the students can share information and ideas in the written form (2017). As a researcher must be able to arrange the words into sentences in the form of the written text in which the reader will eventually understand the ideas and their meaning. Thus, the researcher is demanded to pay the content, organization, vocabulary use, grammatical use, and mechanical considerations such as spelling and punctuation

In general it can be assumed that writing is a thinking process to produce a written text. it is obtained by process of thinking to arrange the words into the sentences, and then the sentences are grouped together into the paragraphs. The result of the written text is reflection of the mental activity of the writer in understanding the context situation that faced by the researcher (Nurul \& Umar, 2017).

\section{Teaching and learning writing}

Because of that, learning to write is not an easy task to do. Many students still make errors and mistakes and, then, they are fossilized (Puspita, 2015). Their interest becomes less and less and students begin to create negative stimuli about learning to write. This condition drives the students to assume that writing is a very difficult task to do. The problem emerges as students are not familiar yet with the types of written discourse in English due to lack of exposure. Consequently, they are not able to or willing to think directly in English. They, then, tend to formulate their ideas in Indonesian language when they express ideas in writing. Afterward they try to translate them into English which is not an easy task and even dangerous. 
However, both teacher and students get difficulties to organize writing practice regularly. Teacher does not have proper time allocation in teaching writing. He or she focuses on another skill. Therefore, teacher gives writing activity to students as an out-of-class activity. Students discover lack of clear specific instruction and also lack of control and monitor from teacher during the writing process. It emerges some new problems to students.

\section{Blended Learning}

Blended learning is an activity conducted by lecturers and teachers that arise both simple and complex one. It is simple because blended learning is the thoughtful integration of classroom face-to-face learning experiences with online learning experiences (Garison and Kanuka, 2004:96). However it is considered as complex activity especially in its implementation with the challenge of virtually limitless design possibilities and applicability to so many contexts.

Kitchenham, A. (2011:4) Blended learning arises flexibility and the flexibility needs technology due to technology simplify teaching and learning process including time and location. Blended Learning maximizing the learning process as well as engaging the students to the process. In university level, blending face to face based course and information and communication technology as well as multimedia and mobile phone will increase interaction and help students with the diverse learning style.

\section{Google Classroom}

Google Classroom is one of online platforms that enhancing teachers' performance in teaching and learning process. It provides a set of features that make it an ideal tool to use by students and the teachers. It is also help teachers save and manage time, keep the classes organized and controlled, and improve communication with students (Iftakhar, 2016).

In addition, Google classroom promotes extensive teaching and learning process that allows teachers to spend more time with their students and less time on the paperwork. Iftakhar (2016) also promotes another benefit of using Google classroom for faculty members. It is stated that Google Classroom has the potential to streamline communication and workflow for students by providing a single access point to discussion threads and assigned work. In addition, it is also mention that Google Classroom can help students to keep their files more organized because all their work can be stored in a single program and they donot need paper for their work. Lecturers or faculty members can easily and quickly identify which students 
may be struggling with their assignments by tracking tasks assigned .Lecturers or faculty members can easily grade the students due to the grading features associated with student submissions.

Another researchers also inform the benefit of Google Classroom. Chehayeb, A. (2015) informs that Google Classroom Software Engineer mentions that they built classroom to save time. Chehayeb claims that Google is launching some features like export grades to Google Sheets, easier to update grade point scale ,keyboard navigation for entering grades, sort by name on grading page etc to save teachers' time. Another benefit is collaborative learning, It is stated by Crawford, A. R. ( 2015) that Google Classroom facilitates collaborative learning. The teacher and lectures can upload materials and can give feedback to students .Students also can upload materials and make personal comment. Moreover, students can collaborate with each other. They can share their documents and assignment and thus they can produce the best assignment. It is also stated by Keeler, A (2014) that Google classroom encourage collaboration between students.

\section{B. METHOD}

This study is descriptive qualitative. It aims at describing the implementation of the blended learning. The subject of the study was English Department students of fourth semester. The data was obtained from interviews and observation. The data obtained then anlayze interactively.

\section{RESULT AND DISCUSSION}

This study described the process of teaching and learning writing using blended learning. Technically, classroom activities that encompasses students and lecturers activities in teaching and learning writing was blanded with google classroom. Moreover, the classroom activities in teaching and learning writing used guided writing.

\section{Classroom Activities}

Guided writing was used by the lecturers, the steps are devided in to three steps; planning, drafting and revising. In addition, Guided Writing can take place: 
Before writing - to support student's planning and drafting of their work. The previous shared session(s) should be referred back to and then extended to further the student's learning in the writing process.

1.The lecturer modelling the process of planning and drafting

2.Developing sentence construction and punctuation

3.Retelling a known story in the correct se-quence

4.Planning a piece of poetry drawn from a model discussed in the shared session

5.Oral rehearsal: in particular, those students who have literacy skills needs

At the point of writing - this can be when the students are beginning to, or havealready begun to write independently. The sessions should be used to praise efforts and offer constructive criticism in order to move learning forward.

1.Write the first or next paragraph of an explanation text and be invited to read it aloud to the group

2.Reread for clarity and purpose

3.Use of consistency in terms of writing traits

4. Use genre-specific vocabulary; choice of phrases, use of complex sentences

5. Re-visit objectives for writing and check their work against the success criteria/rubric

After writing - feedback sessions - Students should be given the opportunity to assess their independent writing. This can be achieved independently or with peer support.

1. Discuss writing targets and agree upon next steps/new target.

2. Support student to edit, proofread and reflect on the impact on the reader

3. Evaluate the students' works by using scoring rubric.

\section{Blending Guided Writing with Google Classroom}

Those classroom activities are not complately done. It is because, those activities need much time. Therefore, to solve the problems, the lecturer use google classroom to support the activities. After clossroom activities, the writing process is continued to Google classroom.

The first step, the lecturer has an account in Google classroom. The the lcturers create the classes. the following picture is the visualitation of the classes on the Google Classroom. In this picture shows that the classrooms consists of six groups.

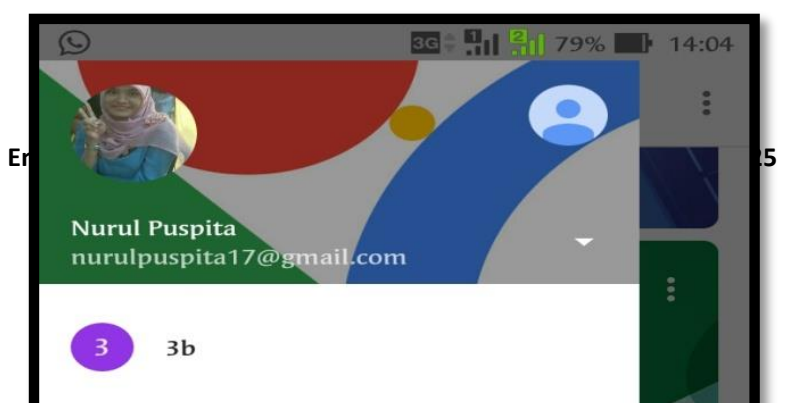




\section{Picture 1. Google Classroom Groups (Writing Class)}

After having group of classes, the lecturer can share the materials to the groups. The following picture shows that lecturer gives new material: Chapter II to group 5D. The materials can be shared and accessed by the lecturer and the students before the class begin.

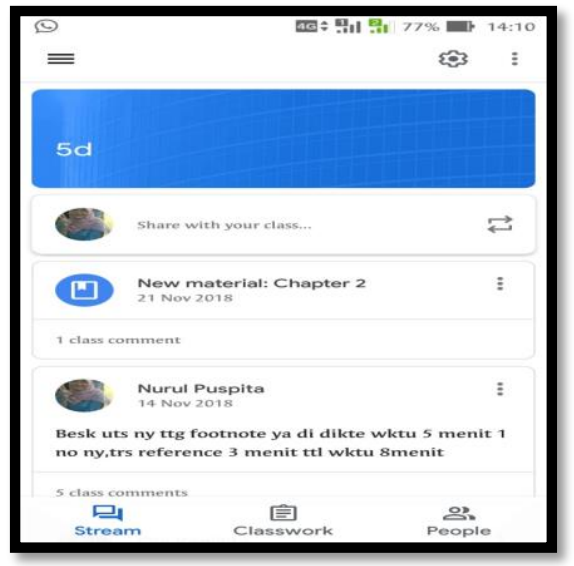

\section{Picture 2. The lecturer shares the materials}

The next step, lecturer gives task to the students. The following is the screen shows that lecturer gives the task to the students. after the task was sent to the groups, the lecturer can check the task. In this case, the lecturer do not need to come in to the classroom manually. Moreover, the students do not need to meet the lecturer physically to consult for the task. These 
processes were conducted on flexibel time and place. The following picture shows the processes.

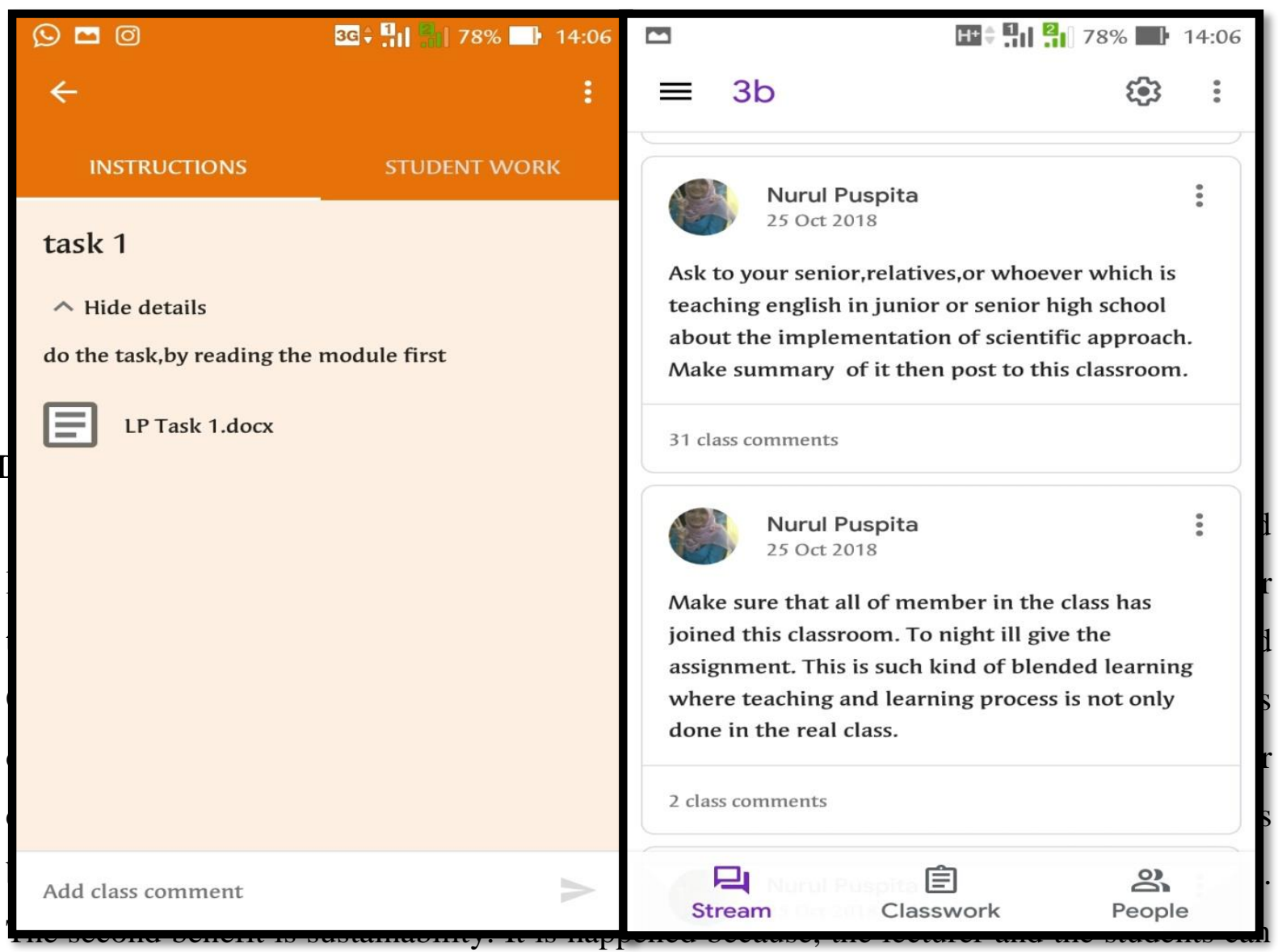

interact easily every time. The third benefit is well-controlled. The lecturer can control the improvement of the students in writing by checkng and discussing the problems or tasks given. It is conducted continuously without time and place restriction.

\section{E. REFERENCES}

Adas, D \& Bakir, A. (2013).Writing Difficulties and New Solutions: Blended Learning as an Approach to Improve Writing Abilities. International Journal of Humanities and Social Science. Vol 3, No. 9. 254-266

Ceylan, O. N. (2019). Student Perceptions of Difficulties in Second Language Writing n. Journal of Language and Linguistic Studies, 15(1), 151-157. Doi:10.17263/jlls.547683

Chehayeb, A. (2015). New in Classroom: saving time while grading. Retrieved from googleforeducation.blogspot.com/2015/12/new-in-Classroom-saving-tim... 
Crawford, .A.R. (2015).Google Classroom.Retrieved from acrawf41.weebly.com/...3/7/ acrawford_emerging technology

Garrison, D. R., \& Kanuka, H. (2004). Blended learning: Uncovering its transformative potential in higher education. The internet and higher education, 7(2), 95-105

Iftakhar, S. (2016). Google classroom: what works and how?. Journal of Education and Social Sciences, 3(1), 12-18.

Janzen, M. (2014). Hot Team: Google Classroom. Retrieved from tlt. psu. edu/2014/12/04/hotteam-Googleclassroom

K Hyland.Teaching Writing and Researching Writing.(London: Pearson Education.2002)

Kitchenham, A. (2011). Blended learning across disciplines: Models for implementation. Hershey, PA: Information Science Reference.

Martin, F and Parker, M. A. (2014). Use of Synchronous Virtual Classrooms: Why, Who,and How? MERLOT Journal of Online Learning and Teaching Vol. 10, No. 2, June $2014 \mathrm{p}$ $192-210$

Murray, D. (1972). Teach writing as a process not product. The Leaflet, 71(3), 11-14.

Nurul, P., \& Umar Al Faruq, A. H. (2017). Discourse Analysis on the Cohesion of Descriptive Writing Produced by Students of UIN RIL Lampung. Jurnal Iqra': Kajian Ilmu Pendidikan, 2(2), 347-365.

Peter Grundy. Beginning to Write: Writing Activity for elementary and Intermediate Learners. (Cambridge: Cambridge University Press, 1991),p.7.

Puspita, N. (2015). THE EFFECTIVENESS OF FOUR SQUARE WRITING IN TEACHING WRITING VIEWED FROM STUDENTS'CREATIVITY. English Education: Jurnal Tadris Bahasa Inggris, 7(1), 64-80.

Sari, Y. A., \& Suhono, S. (2017). Applaying Transition Action Detail Strategy on Written Text of EFL Young Learners. Jurnal Iqra': Kajian Ilmu Pendidikan, 2(1), 1-24.

Suhono Suhono, - An ANALYSIS OF WRITTEN ERROR AMONG EFL STUDENTS OF ENGLISH PROFICIENCY LEVEL OF INTERNATIONAL PROGRAM,\| Pedagogy: Journal of English Language Teaching 4, no. 1 (2017): 72-81.

Suhono Suhono, -SURFACE STRATEGY TAXONOMY ON THE EFL STUDENTS'COMPOSITION A STUDY OF ERROR ANALYSIS,\| Iqra': Jurnal Kajian Ilmu Pendidikan 1, no. 2 (2017): 1-30. 